\title{
Proteolytic Activation and Inactivation of Chitin Synthase from Neurospora crassa
}

\author{
By ANGEL ARROYO-BEGOVICH*† AND JOSE RUIZ-HERRERA $\dagger$ \\ * Departamento de Biología Experimental, Instituto de Biología, \\ Universidad Nacional Autónoma de México \\ †Departamento de Genética y Biología Molecular, \\ Centro de Investigación y Estudios Avanzados del I.P.N., México, D. F., México
}

(Received 30 October 1978; revised 31 January 1979)

The proteolytic activation and inactivation of chitin synthase (EC 2.4.1.16) from Neurospora crassa was studied. Chitin synthase was found mostly in an inactive form which could be activated either endogenously or by the addition of exogenous proteases. The addition of protease inhibitors prevented the endogenous activation of the enzyme. The stability of the inactive enzyme improved when buffers of $\mathrm{pH}$ values between 8.2 and 9.5 were employed. The inactive enzyme was mainly associated with membranous fractions.

\section{INTRODUCTION}

Biosynthesis of chitin in a cell-free system was first described for Neurospora crassa (Glaser \& Brown, 1957). In subsequent studies, synthesis of chitin has been obtained with cell-free extracts of various organisms (Jaworsky et al., 1965; Porter \& Jaworsky, 1966; Camargo et al., 1967; Keller \& Cabib, 1971; McMurrough et al., 1971; Jan, 1974; Moore \& Peberdy, 1975; Peberdy \& Moore, 1975; Gooday \& de Rousset-Hall, 1975; Ruiz-Herrera et al., 1975; López-Romero \& Ruiz-Herrera, 1976; Moore \& Peberdy, 1976; Archer, 1977; Ruiz-Herrera et al., 1977; Braun \& Calderone, 1978; Isaac et al., 1978; Van Laere \& Carlier, 1978). While studies of chitin synthase (UDP-2-acetamido-2-deoxy-D-glucose: chitin 4- $\beta$-acetamidodeoxyglucosyltransferase; EC 2.4.1.16) in $N$. crassa have not been pursued further, studies with Saccharomyces cerevisiae (Ulane \& Cabib, 1976), Mucor rouxii (Ruiz-Herrera \& Bartnicki-García, 1976) and Aspergillus nidulans (Ryder \& Peberdy, 1977; Isaac et al., 1978) have provided more understanding of the regulation of chitin synthase. Mucor rouxii, a dimorphic organism, has been used for a comparative study of the properties of chitin synthase in mycelial and yeast forms. The yeast and mycelial enzymes were similar except that the former was predominantly inactive and was slowly activated during incubation, whereas the mycelial enzyme was found mostly in its active state and on incubation was rapidly inactivated (Ruiz-Herrera \& Bartnicki-García, 1976). Since $N$. crassa grows only in a mycelial form it was of interest to examine whether its chitin synthase was present predominantly in an active state, as in the mycelial form of $M$. rouxii, or in an inactive form. This paper describes the effect of exogenous proteases and protease inhibitors on the activity of chitin synthase from N. crassa, the existence of an active and an inactive form of the enzyme, the effect of $\mathrm{pH}$ on the stability of both enzymic forms, and their subcellular distribution. In the absence of definite proof of the nature of inactive chitin synthase, we have refrained from using the terms zymogen and zymogenic to describe it.

$\ddagger$ Present address: Department of Plant Pathology, University of California, Riverside, California 92521, U.S.A. 


\section{METHODS}

Cultivation. Stock cultures of Neurospora crassa wild-type strain 74A were maintained on slants of Vogel's minimal medium (Vogel, 1956) plus $2 \%(\mathrm{w} / \mathrm{v})$ sucrose and $2 \%(\mathrm{w} / \mathrm{v})$ agar. Spore suspensions were obtained by inoculating a loopful of conidia into $125 \mathrm{ml}$ Erlenmeyer flasks containing $25 \mathrm{ml}$ Vogel's minimal medium supplemented as above and incubating in constant light for $6 \mathrm{~d}$ at $25^{\circ} \mathrm{C}$. Conidia obtained from several flasks were suspended in $15 \mathrm{ml}$ of cold, sterile distilled water, filtered through sterile glass wool to remove fragments of mycelium, washed once with sterile water and centrifuged. Carboy flasks (20 1) containing 15 I Vogel's minimal medium with $2 \%$ sucrose were inoculated with $2 \times 10^{6}$ conidia $\mathrm{ml}^{-1}$ and incubated for 48 to $55 \mathrm{~h}$ at $28^{\circ} \mathrm{C}$ with vigorous aeration. Mycelium was harvested by filtration through two layers of cheesecloth, washed once with cold distilled water and lyophilized. Dry mycelium was ground to a fine powder in a Wiley mill and kept at $-10^{\circ} \mathrm{C}$ until used.

Preparation of cell-free extracts. Two different buffer systems were employed in the preparation and fractionation of cell-free extracts - $50 \mathrm{~mm}$-Tris/ $\mathrm{HCl}$ and $50 \mathrm{~mm}$-glycine/ $\mathrm{NaOH}$, both containing $10 \mathrm{~mm}-$ $\mathrm{MgCl}_{2}$ and $1 \mathrm{~mm}-\mathrm{mDTA}$ and adjusted to the indicated $\mathrm{pH}$ values. Mycelium powder (700 mg) was resuspended in $25 \mathrm{ml}$ buffer, mixed with $15 \mathrm{ml}$ glass beads $(0.45$ to $0.50 \mathrm{~mm})$ and homogenized for $45 \mathrm{~s}$ in a Braun MSK cell homogenizer cooled with compressed $\mathrm{CO}_{2}$. Mycelium homogenates were first centrifuged at $1000 \mathrm{~g}$ for $5 \mathrm{~min}$ to eliminate the wall fraction and then at $65000 \mathrm{~g}\left(r_{\mathrm{av}}\right)$ for $40 \mathrm{~min}$. The pellet (mixed membrane fraction, MMF) was resuspended in the same buffer with the aid of a tissue homogenizer and recentrifuged. The resulting pellet was used without further treatment.

Chitin synthase assay. The assay procedure was similar to that described by Ruiz-Herrera \& BartnickiGarcía (1976), except that the buffer employed was $50 \mathrm{~mm}$-Tris $/ \mathrm{HCl}, \mathrm{pH} \mathrm{7 \cdot 5}$. The standard reaction mixture contained 0.5 mM-UDP-[ $\left.{ }^{14} \mathrm{C}\right] \mathrm{GlcNAc}\left(0.20 \mathrm{Ci} \mathrm{mol}^{-1}\right), 20 \mathrm{~mm}-\mathrm{GlcNAc}, 0.2 \mathrm{~mm}-\mathrm{ATP}, 10 \mathrm{~mm}-\mathrm{MgCl}_{2}, 50 \mathrm{~mm}-$ Tris $/ \mathrm{HCl}$ buffer, $\mathrm{pH} 7 \cdot 5$, and enzyme in a final volume of $0.125 \mathrm{ml}$; where indicated the assay mixture also contained various amounts of different proteases or protease inhibitors. After incubation for $30 \mathrm{~min}$, the enzymic reaction was stopped by adding about $0 \cdot 1 \mathrm{ml} 1 \mathrm{M}-\mathrm{NaOH}$. The radioactivity incorporated into chitin was measured as described by Ruiz-Herrera \& Bartnicki-García (1976). Chitin synthase activity was expressed as nmol GlcNAc incorporated $\mathrm{min}^{-1}$. Specific activity was related to $1 \mathrm{mg}$ protein.

Protein measurement. Protein was measured by Lowry's method.

Chemicals. UDP-[ $\left.{ }^{14} \mathrm{C}\right] \mathrm{GlcNAc}$ was purchased from New England Nuclear. Rennilase, an acid protease, from Mucor miehei was a gift from Novo Enzyme Co. (Mamaroneck, N.Y., U.S.A.). Acid proteases (from Aspergillus oryzae cat. no. p4755 and from Streptomyces caespitosus cat. no. p0384) and neutral proteases (from Bacillus subtilis cat. no. p5380 and from Bacillus amyloliquefaciens cat. no. p5255) and trypsin were purchased from Sigma, as was the protease inhibitor phenylmethylsulphonyl fluoride (PMSF). The protease inhibitors Antipain and Chymostatin were a gift from Professor H. Umezawa (Microbial Research Foundation, Tokyo, Japan). Pepstatin A was purchased from the Protein Research Foundation (Osaka, Japan).

\section{RESULTS}

\section{Effect of exogenous proteases on chitin synthase activity}

Several proteases at various concentrations were added directly to the assay mixture. Neutral proteases were more effective than acid proteases in stimulating chitin synthase activity (Fig. 1) and trypsin was the most effective of all proteases tested. Two of the acid proteases showed stimulatory activity comparable to that of the neutral proteases only when present at 20- to 50-fold higher concentrations. Rennilase, an acid protease which is highly effective in activating chitin synthase from $M$. rouxii, exhibited minimal stimulatory activity in the $N$. crassa system. In all experiments the final pH was 7.5 and this should be taken into consideration in assessing the relative effectiveness of the proteases. Neurospora crassa behaved similarly to $S$. cerevisiae and Agaricus bisporus whose chitin synthases are more efficiently activated by neutral proteases (Bartnicki-García et al., 1978).

\section{Stability of chitin synthase and the effect of protease inhibitors on its activation and inactivation}

Samples of MMF were incubated in buffer, $\mathrm{pH} 8 \cdot 6$, at $30{ }^{\circ} \mathrm{C}$ either alone or in the presence of one of several protease inhibitors. At intervals, samples were withdrawn and chitin synthase was measured in the absence of trypsin. With most of the protease inhibitors tested, chitin synthase activity was lost at a slightly higher rate than from the control (without inhibitor), 


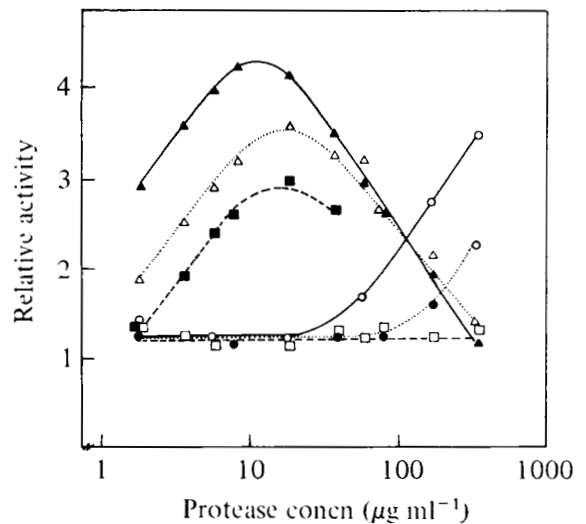

Fig. 1

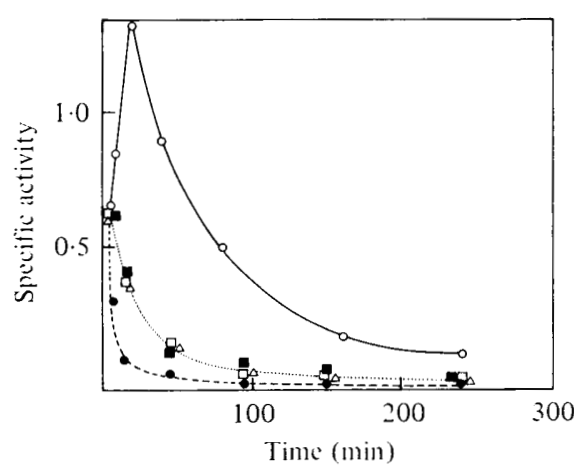

Fig. 2

Fig. 1. Effect of proteases on chitin synthase activity of $N$. crassa. Protease solutions (freshly prepared in $50 \mathrm{~mm}$-Tris/ $\mathrm{HCl}$ buffer, $\mathrm{pH} \mathrm{7.5)}$ were added to standard chitin synthase assays to give the required concentration. Reactions were started by adding MMF $(0 \cdot 134 \mathrm{mg}$ protein) suspended in $50 \mathrm{~mm}$-Tris/HCl buffer, pH 8.6. Incorporation of GlcNAc into chitin was measured as described in Methods. Calculated specific activities are expressed relative to that of a control without protease $(1 \cdot 00)$; the control had a specific activity of $2.38 \mathrm{nmol}$ GlcNAc incorporated (mg protein) ${ }^{-1} \mathrm{~min}^{-1}$. $\bigcirc$, Acid protease (Streptomyces caespitosus); 0 , acid protease (Aspergillus oryzae); $\square$, rennilase (Mucor miehei); neutral protease (Bacillus subtilis); $\triangle$, neutral protease (Bacillus amyloliquefaciens); $\boldsymbol{\Delta}$, trypsin.

Fig. 2. Effect of protease inhibitors on the activation and inactivation of chitin synthase of $N$. crassa. MMF was suspended in $50 \mathrm{mM}$-Tris/ $\mathrm{HCl}$ buffer, $\mathrm{pH} 8.6\left(8.0 \mathrm{mg}\right.$ protein $\left.\mathrm{ml}^{-1}\right)$ and samples $(1 \mathrm{ml})$ were incubated at $30^{\circ} \mathrm{C}$ in the presence or absence of protease inhibitors. Samples $(25 \mu \mathrm{l})$ were withdrawn at intervals and chitin synthase activity was assayed in the absence of trypsin as described in Methods. Specific activities are expressed as nmol GlcNAc incorporated (mg protein) ${ }^{-1}$. $\bigcirc$, No inhibitor added;, $\operatorname{PMSF}(20 \mathrm{~mm}) ; \square$, Antipain $\left(5 \mu \mathrm{g} \mathrm{ml}^{-1}\right) ; \boldsymbol{w}$, Chymostatin $\left(5 \mu \mathrm{g} \mathrm{ml}^{-1}\right)$; $\triangle$, Pepstatin $\left(5 \mu \mathrm{g} \mathrm{ml}^{-1}\right)$.

but with PMSF, activity was lost at a much higher rate (Fig. 2). The control sample showed an initial net increase of chitin synthase activity, but this did not occur in the presence of any of the protease inhibitors.

\section{Effect of $p H$ on the stability of chitin synthase}

The above results showed that chitin synthase is unstable when prepared as described by Glaser \& Brown (1957). In attempts to improve the stability of the enzyme, the effect of $\mathrm{pH}$ was tested. Mycelium homogenates were prepared and fractionated as described in Methods, using buffers of different $\mathrm{pH}$ values. The resulting mixed membrane fractions were incubated at $30{ }^{\circ} \mathrm{C}$ for $3 \mathrm{~h}$. Above $\mathrm{pH} 8 \cdot 0$, the enzyme stability increased sharply and at $\mathrm{pH}$ values between 8.25 and $9 \cdot 5,80 \%$ of the initial activity was retained (Fig. 3). When stabilized enzyme maintained at alkaline $\mathrm{pH}$ for several hours was returned to $\mathrm{pH} 7 \cdot 0$, chitin synthase was rapidly inactivated. Chitin synthase activity may therefore be destroyed by an enzyme which is inactive but stable at alkaline $\mathrm{pH}$.

\section{Activation and inactivation of preactivated and latent chitin synthase}

When MMF was incubated at pH 8.6 and assayed in the absence of trypsin, it showed first a 2-fold net increase in total chitin synthase activity, followed by a rapid loss of activity (Figs 2, 4). However, when MMF was assayed in the presence of trypsin, the total activity detected initially was 10 -fold higher than that found in the absence of trypsin. On continued incubation a slight increase in activity $(1 \cdot 1$-fold), was observed, but subsequently loss of enzyme activity was minimal (Fig. 4). Chitin synthase preactivated with trypsin (with further action of the protease stopped by the addition of soy bean trypsin inhibitor) was much less stable than inactive chitin synthase (results not shown). 


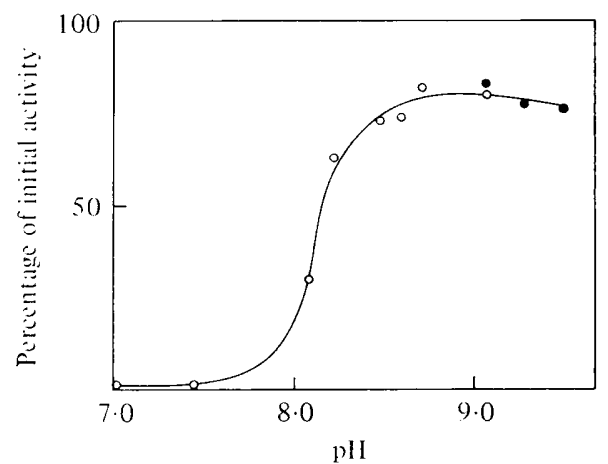

Fig. 3

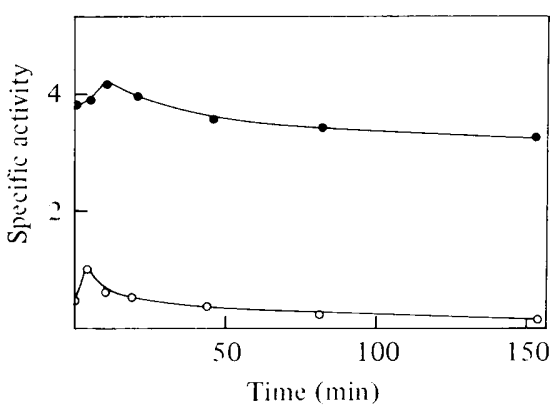

Fig. 4

Fig. 3. Effect of $\mathrm{pH}$ on the stability of chitin synthase of $N$. crassa. MMF was suspended (3 mg protein $\mathrm{ml}^{-1}$ ) in either $50 \mathrm{~mm}$-Tris/HCl buffer $(O)$ or $50 \mathrm{~mm}$-glycine/NaOH buffer (O), adjusted to the indicated $\mathrm{pH}$ values, and incubated at $30^{\circ} \mathrm{C}$. After $180 \mathrm{~min}$, samples $(25 \mu \mathrm{l})$ were withdrawn and chitin synthase activity was measured at $22^{\circ} \mathrm{C}$ in the presence of trypsin $\left(4 \mu \mathrm{g} \mathrm{ml}^{-1}\right)$ as described in Methods. Results are expressed as percentages of the initial specific activity $[4.5 \mathrm{nmol}$ GlcNAc incorporated (mg protein) ${ }^{-1} \mathrm{~min}^{-1}$.

Fig. 4. Activation and inactivation of active and inactive chitin synthase of $N$. crassa at $30^{\circ} \mathrm{C}$. MMF was suspended in $50 \mathrm{mM}$-Tris/ $\mathrm{HCl}$ buffer, $\mathrm{pH} 8.6\left(3.2 \mathrm{mg}\right.$ protein $\left.\mathrm{ml}^{-1}\right)$ and incubated at $30{ }^{\circ} \mathrm{C}$. Samples $(25 \mu \mathrm{l})$ were withdrawn at intervals and chitin synthase activity was measured at $22{ }^{\circ} \mathrm{C}$ in the absence $(O)$ or presence $(O)$ of trypsin $\left(4 \mu \mathrm{g} \mathrm{ml}^{-1}\right)$ as described in Methods. Specific activities are expressed as nmol GlcNAc incorporated (mg protein $)^{-1} \mathrm{~min}^{-1}$.

\section{Table 1. Distribution of chitin synthase in subcellular fractions of Neurospora crassa}

Fractions were prepared and assayed for chitin synthase activity as described in Methods. Where indicated, trypsin $\left(4 \mu \mathrm{g} \mathrm{ml}^{-1}\right)$ was added to standard chitin synthase assay mixtures. For each fraction, the results show the total activity [nmol GlcNAc incorporated $\mathrm{min}^{-1}$ ], the specific activity [nmol GlcNAc incorporated $\mathrm{min}^{-1}(\mathrm{mg} \text { protein })^{-1}$ ] and the activity in the fraction expressed as a percentage of the total activity in all four fractions.

\begin{tabular}{|c|c|c|c|c|c|c|c|c|c|}
\hline \multirow[b]{3}{*}{ Fraction } & \multirow{2}{*}{\multicolumn{2}{|c|}{$\begin{array}{l}\text { Protein } \\
\text { content } \\
(\mathrm{mg})\end{array}$}} & \multicolumn{7}{|c|}{ Chitin synthase activity } \\
\hline & & & \multicolumn{3}{|c|}{ Without trypsin } & \multicolumn{4}{|c|}{ With trypsin } \\
\hline & Total & $\begin{array}{l}\% \text { of } \\
\text { total }\end{array}$ & $\begin{array}{l}\text { Specific } \\
\text { activity }\end{array}$ & $\begin{array}{c}\text { Total } \\
\text { activity }\end{array}$ & $\begin{array}{l}\% \text { of } \\
\text { total }\end{array}$ & $\begin{array}{l}\text { Specific } \\
\text { activity }\end{array}$ & $\begin{array}{c}\text { Total } \\
\text { activity }\end{array}$ & $\begin{array}{l}\% \text { of } \\
\text { total }\end{array}$ & $\begin{array}{l}\text { Stimulation } \\
\text { by trypsin }(\%)\end{array}$ \\
\hline CWF & $15 \cdot 0$ & $6 \cdot 5$ & $0 \cdot 20$ & $3 \cdot 0$ & $20 \cdot 0$ & $3 \cdot 33$ & $50 \cdot 0$ & $9 \cdot 4$ & $16 \cdot 6$ \\
\hline MMF1 & $60 \cdot 3$ & $26 \cdot 1$ & 0.07 & $4 \cdot 3$ & $28 \cdot 6$ & $4 \cdot 10$ & $247 \cdot 2$ & $46 \cdot 7$ & $57 \cdot 5$ \\
\hline MMF2 & $36 \cdot 2$ & $15 \cdot 6$ & $0 \cdot 21$ & $7 \cdot 7$ & $51 \cdot 3$ & 3.59 & $129 \cdot 7$ & $24 \cdot 5$ & $16 \cdot 8$ \\
\hline $\mathrm{SF}$ & $119 \cdot 5$ & $51 \cdot 7$ & 0.00 & $0 \cdot 0$ & $0 \cdot 0$ & $0 \cdot 86$ & $102 \cdot 1$ & $19 \cdot 3$ & - \\
\hline
\end{tabular}

\section{Distribution of chitin synthase activity in different subcellular fractions and the effect of trypsin on activity}

The buffer employed for cellular fractionation was $50 \mathrm{~mm}$-Tris/ $\mathrm{HCl}, \mathrm{pH} 8 \cdot 6$, containing $10 \mathrm{~mm}^{-\mathrm{MgSO}_{4}}$ and $1 \mathrm{~mm}$-EDTA. Mycelium homogenate prepared as described in Methods was centrifuged for $5 \mathrm{~min}$ at $1000 \mathrm{~g}\left(r_{\mathrm{av}}\right)$ to collect the cell wall fraction (CWF). This fraction was washed eight times and finally resuspended in $25 \mathrm{ml}$ buffer. The supernatant was centrifuged for $30 \mathrm{~min}$ at $13500 \mathrm{~g}\left(r_{\mathrm{ar} .}\right)$ and the pellet (fraction MMFl) was washed twice and resuspended in $6 \mathrm{ml}$ buffer. The $13500 \mathrm{~g}$ supernatant was centrifuged for $60 \mathrm{~min}$ at $65000 \mathrm{~g}\left(r_{\mathrm{av} .}\right)$ and the pellet (fraction MMF2) was washed once and resuspended in $4 \mathrm{ml}$ buffer. The final supernatant $(18.5 \mathrm{ml})$ was designated the cytosol (SF) fraction. Activity in each fraction was determined in the presence or absence of trypsin at a final concentration of $4 \mu \mathrm{g} \mathrm{ml}^{-1}$. From the results (Table 1), it appeared that in the absence of protease all chitin synthase activity was associated with the particulate fractions $-28.6 \%$ in fraction 
MMF1, $51.3 \%$ in fraction MMF2 and $20.0 \%$ in the wall fraction (CWF). When assays were carried out in the presence of trypsin, stimulations of 57-, 17- and 17-fold for the chitin synthase activity of MMF1, MMF2 and CWF, respectively, were obtained. In the absence of trypsin, the cytosol fraction (SF) exhibited negligible chitin synthase activity; however, assay in the presence of trypsin demonstrated the existence of inactive chitin synthase activity amounting to $19 \%$ of the total chitin synthase of the cell-free extract. The cytosol from $N$. crassa contains a protein inhibitor of chitin synthase (Arroyo-Begovich \& ZarainHerzberg, unpublished results) similar to that described for $M$. rouxii (López-Romero et al., 1978). Therefore, the amount of chitin synthase found in the cytosol fraction represents a minimum estimate.

\section{DISCUSSION}

Chitin synthase in extracts of Neurospora crassa was present mainly in an inactive form. The inactive enzyme was activated by proteolytic action, trypsin being the most efficient agent. This suggests that either the enzyme is produced in the cell as a true zymogen which is activated by breakage at a specific point in the molecule or that the enzyme is masked by the presence of an inhibitory factor which is released by partial digestion.

Proteolytic activation of chitin synthase has been described for Saccharomyces carlsbergensis and Saccharomyces cerevisiae (Cabib \& Farkas, 1971), the dimorphic fungus Mucor rouxii (Ruiz-Herrera \& Bartnicki-García, 1976) and for the filamentous fungi Aspergillus flavus (López-Romero \& Ruiz-Herrera, 1976) and Aspergillus nidulans (Ryder \& Peberdy, 1977; Isaac et al., 1978). Our studies on the activation and inactivation of the enzyme from $N$. crassa indicate that most of chitin synthase is present in an inactive state. This inactive form is stable at $\mathrm{pH}$ values above $8 \cdot 0$, but once activated (either endogenously or exogenously), the enzyme becomes unstable and is rapidly inactivated. Since protease inhibitors did not prevent the destruction of chitin synthase three possibilities can be considered: (i) inactivation is not due to a protease but to a different enzymic mechanism; (ii) the inactivating protease is of an unusual type resistant to all inhibitors tested; (iii) inactivating protease is firmly bound to chitin synthase and thus it is not reached by protease inhibitors. Similar results and explanations were reported for mycelial chitin synthase from M. rouxii (Sentandreu \& Ruiz-Herrera, 1978).

Chitin synthase was activated by exogenous proteases or by an endogenous process; of the proteases tested, the neutral ones were the most effective. Bartnicki-García et al. (1978) found differences in the effectiveness of several proteases in activating chitin synthases from different fungi. These differences may represent intrinsic properties of the enzyme from each fungus.

The endogenous activation of chitin synthase observed is probably due to the action of a protease present in the extracts since in the presence of proteolytic inhibitors no endogenous activation was found. We observed that the rate of apparent destruction of the enzyme was greater in the presence of PMSF. This suggests that PMSF is more effective than Antipain and Chymostatin in preventing the activation of the enzyme, presumably by inhibiting an activating serine-protease without affecting the inactivating process. It is difficult to explain why endogenous activation of the enzyme is prevented by both neutral protease inhibitors (PMSF, Antipain and Chymostatin) and acid protease inhibitors (Antipain). Possibly, endogenous activation of the enzyme requires the participation of acidic and neutral proteases.

It has been proposed that the regulation of chitin synthase activity is responsible for the pattern of wall construction. For Saccharomyces spp., a molecular model was proposed by which activation of chitin synthase allows for chitin synthesis to occur at a precise time and location within the cell (Cabib \& Farkas, 1971; Ulane \& Cabib, 1976). In M. rouxii, proteolytic activation and inactivation of chitin synthase are thought to be at least partly responsible for the differences in wall construction between the mycelial and yeast forms (Ruiz-Herrera \& Bartnicki-García, 1976). 
The properties of chitin synthase activity in $N$. crassa suggest that in vivo a delicate balance exists between the activation and inactivation of the enzyme which is responsible for the pattern of wall growth of the fungus. Almost all chitin synthase in $N$. crassa exists in an inactive form. Enzyme present in the different membrane fractions probably represents the precursor form (endoplasmic reticulum) and that located in its site of action (plasmalemma and/or wall). The enzyme present in the cytosol represents the recently described microvesicles called chitosomes (Bracker et al., 1976; Ruiz-Herrera et al., 1977; BartnickiGarcía et al., 1978). These microvesicles could carry the inactive enzyme to the apical dome of the growing hyphae where it would be activated. After synthesis of chitin had taken place, the enzyme would be destroyed so that apical growth is maintained.

This work was supported in part by subvention PNCB no. 071, CONACYT, México.

\section{REFERENCES}

Archer, D. B. (1977). Chitin biosynthesis in protoplasts and subcellular fractions of Aspergillus fumigatus. Biochemical Journal 164, 653-658.

Bartnicki-García, S., Bracker, C. E., Reyes, E. \& Ruiz-Herrera, J. (1978). Isolation of chitosomes from taxonomically diverse fungi and synthesis of chitin microfibrils in vitro. Experimental Mycology 2, 173-192.

Bracker, C. E., Ruiz-Herrera, J. \& BartnickiGarcía, S. (1976). Structure and transformation of chitin synthetase particles (chitosomes) during microfibril synthesis in vitro. Proceedings of the National Academy of Sciences of the United States of America 73, 4570-4574.

Braun, P. C. \& Calderone, R. A. (1978). Chitin synthesis in Candida albicans: comparison of yeast and hyphal forms. Journal of Bacteriology 135, 1472-1477.

CABIB, E. \& FARKas, V. (1971). The control of morphogenesis: an enzymatic mechanism for the initiation of septum formation in yeast. Proceedings of the National Academy of Sciences of the United States of America 68, 2052-2056.

Camargo, E. P., Dietrich, C. P., Sonneborn, D. \& Strominger, J. L. (1967). Biosynthesis of chitin in spores and growing cells of Blastocladiella emersonii. Journal of Biological Chemistry 242, $3121-3128$.

Glaser, L. \& Brown, D. H. (1957). The synthesis of chitin in cell free extracts of Neurospora crassa. Journal of Biological Chemistry 228, 729-742.

Gooday, G. W. \& de Rousset-Hall, A. (1975). Properties of chitin synthetase from Coprinus cinereus. Journal of General Microbiology 89, $137-145$.

IsaAc, S., Ryder, N. S. \& Peberdy, J. F. (1978). Distribution and activation of chitin synthetase in protoplast fractions released during the lytic digestion of Aspergillus nidulans hyphae. Journal of General Microbiology 105, 45-50.

JAN, Y. N. (1974). Properties and cellular localization of chitin synthetase in Phycomyces blakesleeanus. Journal of Biological Chemistry 249, 1973-1979.

Jaworski, E. G., Wang, L. C. \& Carpenter, W. D. (1965). Biosynthesis of chitin in cell-free extracts of Venturia inaequalis. Phytopathology 55, 13091312.
Keller, F. A. \& CABIB, E. (1971). Chitin and yeast budding. Properties of chitin synthetase from Saccharomyces carlsbergensis. Journal of Biological Chemistry 246, 160-166.

López-Romero, E. \& Ruiz-Herrera, J. (1976). Synthesis of chitin by particulate preparations from Aspergillus flavus. Antonie van Leeuwenhoek 42, 261-276.

López-Romero, E., Ruíz-Herrera, J.\& BARTNICKIGarcía, S. (1978). Purification and properties of an inhibitory protein of chitin synthetase from Mucor rouxii. Biochimica et biophysica acta 525, 338-345.

McMurrough, I., Flores-Carreón, A. \& Bartnicki-García, S. (1971). Pathway of chitin synthesis and cellular localization of chitin synthetase in Mucor rouxii. Journal of Biological Chemistry 246, 3999-4007.

Moore, P. M. \& Peberdy, J. F. (1975). Biosynthesis of chitin by particulate fractions from Cunninghamella elegans. Microbios 12, 29-39.

Moore, P. M. \& Peberdy, J. F. (1976). A particulate chitin synthase from Aspergillus flavus Link: the properties, location and levels of activity in mycelium and regenerating protoplast preparations. Canadian Journal of Microbiology 22, 915921.

Peberdy, J. F. \& Moore, P. M. (1975). Chitin synthase in Mortierella vinacea: properties, cellular location and synthesis in growing cultures. Journal of General Microbiology 90, 228-236.

Porter, C. A. \& JAworski, E. F. (1966). The synthesis of chitin by particulate preparations of Allomyces macrogynus. Biochemistry 5, 1149-1154.

Ruiz-Herrera, J. \& Bartnicki-García, S. (1976). Proteolytic activation and inactivation of chitin synthetase from Mucor rouxii. Journal of General Microbiology 97, 241-249.

Ruiz-Herrera, J., Sing, V. O., van der Woude, W. J. \& BARTNiCKi-García, S. (1975). Microfibril assembly by granules of chitin synthetase. Proceedings of the National Academy of Sciences of the United States of America 72, 2706-2710.

Ruiz-Herrera, J., López-Romero, E. \& BartNickiGarcía, S. (1977). Properties of chitin synthetase in isolated chitosomes from yeast cells of Mucor rouxii. Journal of Biological Chemistry 252, 3338-3343. 
Ryder, N. S. \& Peberdy, J. F. (1977). Chitin synthase in Aspergillus nidulans: properties and proteolytic activation. Journal of General Microbiology 99, 69-76.

Sentandreu, R. \& Ruiz-Herrera, J. (1978). In situ study of the localization and regulation of chitin synthetase in Mucor rouxii. Current Microbiology 1, 77-80.

Ulane, R. E. \& CABIB, E. (1976). The activating system of chitin synthetase from Saccharomyces cerevisiae. Journal of Biological Chemistry 251, 3367-3374.

Van Laere, A. J. \& Carlier, A. R. (1978). Synthesis and proteolytic activation of chitin synthetase in Phycomyces blakesleeanus Burgeff. Archives of Microbiology 116, 181-184.

Vogel, H. J. (1956). A convenient growth medium for Neurospora (medium N). Microbial Genetics Bulletin 13, 42-43. 